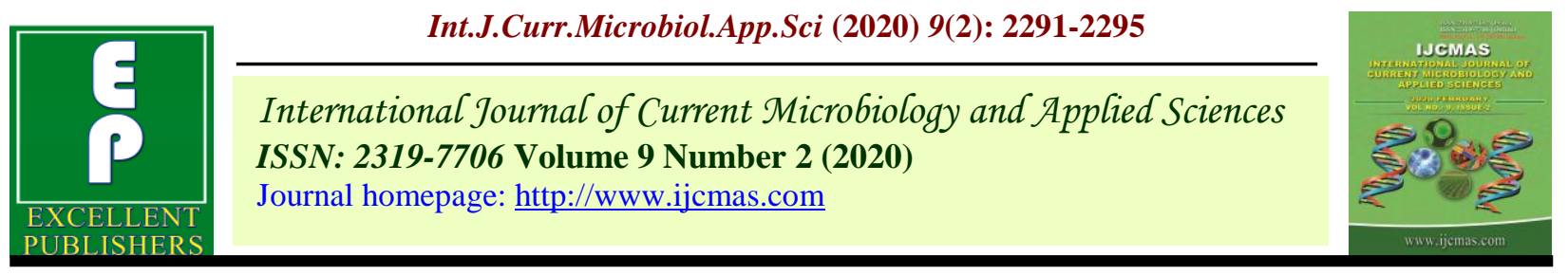

Original Research Article

https://doi.org/10.20546/ijcmas.2020.902.259

\title{
Performance Evaluation of Power Weeder for Paddy Crop
}

\author{
Narendra H. Tayade* and Birbal Sahu
}

Farm Machinery and Power Engineering, Krishi Vigyan Kendra Kanker, India

*Corresponding author

Keywords

Field capacity, Single row power weeder, Weeding efficiency, Energy consumption

Article Info

Accepted:

15 January 2020

Available Online:

10 February 2020

A B S T R A C T

A power operated single row weeder for inter row weeding was evaluated in rice crop and compared with traditional methods of manual weeding in farmers field at Krishi Vigyan Kendra Kanker (CG). The power weeder consisted of engine, blades assembly and transmission system. In this study, field experiments was conducted in paddy field during the year 2018-19 kharif season to evaluate the working capacity, weeding efficiency, costs of operation and energy required per unit area were calculated. The result indicated that actual field capacity was $0.044 \mathrm{ha} / \mathrm{h}$ with a field efficiency 67.19 per cent and weeding efficiency was found to be 81.88 per cent. The minimum cost of weeding operation was observed under power operated weeder i.e. Rs. $1580 \mathrm{ha}^{-1}$ whereas in farmers practice cost was Rs $5108 \mathrm{ha}^{-1}$. Similarly energy -cost ratio was $2.02 \mathrm{Rs} \mathrm{MJ}^{-1}$ and 14.33 Rs $\mathrm{MJ}^{-1}$ in power operated weeder and in farmers practice respectively.

\section{Introduction}

Rice is the main crop of kanker district which is growing in 1.83 lakh ha, which is around 79 per cent of total cropped area. Weeding in rice crop is timely operation to be executed to get maximum yield otherwise weed will compete for the nutrients with crop. In traditional method of rice cultivation, weeds are mostly removed from the field with manual process as they are seen more as a negative factor for crop growth i.e. manually weeding is one of the time and energy consuming operation and also labour cost increasing tremendously from last decade Hence cost of cultivation is getting increased every day. The chemical weeding is one of the effective method but it leads to various environmental and health issues. Now a days Govt. is giving more emphasize on line sowing and provide subsidy on seed drills and rice transplanters to increase production and productivity. But weeding is a major problem in line sown rice crop. Hence there is need to doing weeding 
operation timely with low cost mechanical weeding to increase the crop yield and also the framers of uttar baster kanker district have been interested to grown organic rice. Keeping the above point in view, the study was undertaken to evaluate the performance of power operated single row weeder for inter row weeding of rice crop in farmers field at Krishi Vigyan Kendra Kanker.

\section{Materials and Methods}

The machine performance parameters such as weeding efficiency, plant damaged, effective field capacity, theoretical field capacity, field efficiency, and fuel consumption of power weeder were determined for the performance evaluation and are determined as follows.

\section{Weeding efficiency}

It is the ratio between the numbers of weeds removed by power weeder to the number of weeds present in a unit area and is expressed as a percentage. The samplings were done by quadrant method, by randomly selection of spots by a square quadrant of 1 square meter (Tajuddin, 2006).

Weeding efficiency $(\%)=\mathrm{W} 1-\mathrm{W} 2 / \mathrm{W} 1$

Where,

$\mathrm{W} 1$ = Number of weeds counted per unit area before weeding operation

W2 $=$ Number of weeds counted in same unit area after weeding operation

\section{Plant damage}

It is the ratio of number of plant damaged after operation in a row to the number of plants present in that row before operation. It is expressed in percentage. Plant damage (\%) $=(1-\mathrm{q} / \mathrm{p}) \times 100$
Where,

$\mathrm{p}=$ Number of plants in a $10 \mathrm{~m}$ row length of field before weeding.

$\mathrm{q}=$ Number of plants in a $10 \mathrm{~m}$ row length of field after weeding.

\section{Effective field capacity}

Effective field capacity is the actual average rate of coverage by the machine, based upon the total field time. It is a function of the rated width of the machine, the percentage of rated width actually utilized, speed of the travel and the amount of field time lost during the operation. Effective field capacity is usually expressed as hectare per hour (Kepner et al., 1978).

$\mathrm{EFC}=\mathrm{A} / \mathrm{Tp} \times \mathrm{Ti}$ Where, $\mathrm{EFC}=$ Effective field capacity, ha/h

$\mathrm{A}=$ Actual area covered, ha $\mathrm{Tp}=$ Productive time, $\mathrm{h} \mathrm{Ti}=$ Non-productive time, $\mathrm{h}$

\section{Theoretical field capacity}

Theoretical field capacity of the machine is the rate of field coverage that would be obtained if the machine were performing its function $100 \%$ of the time at the rated forward speed and always covered $100 \%$ of its rated width. It is expressed as hectare per hour and determined as follows

TFC $=\mathrm{w} \times \mathrm{s} / 10$ Where, $\mathrm{TFC}=$ Theoretical field capacity, ha/h $\mathrm{w}=$ Width of cut, $\mathrm{m} \mathrm{s}=$ Speed of operation, $\mathrm{Km} / \mathrm{h}$

\section{Field efficiency}

Field efficiency is the ratio of effective field capacity to the theoretical field capacity, expressed as percentage. It includes the effect of time lost in the field and of failure to utilize the full width of the machine. 
$\eta \mathrm{e}=\mathrm{EFC} / \mathrm{TFC} \times 100$ Where, $\eta \mathrm{e}=$ Field efficiency, \% EFC = Effective field capacity, $\mathrm{ha} / \mathrm{h} \mathrm{TFC}=$ Theoretical field capacity, ha/h

\section{Fuel consumption}

The fuel consumption has direct effect the economics of the power weeder. It was measured by top fill method. The fuel tank was filled to full capacity before the testing at leveled surface. After completion of test operation, amount of fuel required to top fill again is the fuel consumption for the test duration. It was expressed in liter per hour or liter per hectare (Table 1).

\section{Results and Discussion}

A power operated single row weeder for inter row weeding was tested for 20 DAS and 40 DAS on the basis of field capacity, field efficiency, weeding efficiency, energy consumption and cost of operation. The effective field capacity was $0.044 \mathrm{ha} / \mathrm{h}$. Field efficiency was found to be 67.19 The weeding efficiency as 81.88 per cent, the operating cost of the rotary paddy weeder was Rs.1580/ha compared to Rs. 5108 /ha for manual weeding . Average fuel consumption of $0.66 \mathrm{l} / \mathrm{h}$. The saving in cost of weeding was 69 per cent compared to manual weeding.

The minimum energy- cost was depicted by treatment single row power weeder) and it was found to be $2.02 \mathrm{Rs} / \mathrm{MJ}$ as compared to manual weeding (14.33 Rs/MJ)

In conclusion, single row power weeder uproots the weeds inline sowing of rice shows significant for the farmers as it reduces time as well as cost of weeding operation compared to conventional weeding operation and energy consumption promotes the necessity of mechanized weeding.

Table: Technical specifications of the single row power weeder

S.No. Specification

1 Engine maximum power

2 Overall dimension $\mathrm{mm}$

$3 \quad$ Weeding width

$4 \quad$ No. of Blades

$5 \quad$ Rotor speed

$6 \quad$ Weeding depth

7 Total weight

$8 \quad$ Cost of machine
Value

$2 \mathrm{hp}$ at $6000 \mathrm{rpm}$

1345.8 x 573 x $1020(\mathrm{LxWxH})$

$140 \mathrm{~mm}$ to $250 \mathrm{~mm}$

8

$176 \mathrm{rpm}$

$3-8 \mathrm{~cm}$

$14.5 \mathrm{~kg}$

Rs $27,000 /-$ 
Table.1 Field performance of single row power weeder

\begin{tabular}{|l|l|l|}
\hline S. No. & Particulars & Farmer's fields \\
\hline $\mathbf{1}$ & Average depth of water, mm & $25-30$ \\
\hline $\mathbf{2}$ & Area covered, ha & 2.05 \\
\hline $\mathbf{3}$ & Crop variety & Chandrahasani \\
\hline $\mathbf{4}$ & Days after transplanting, days & 20 and 40 \\
\hline $\mathbf{5}$ & Row to row spacing, mm & 250 \\
\hline $\mathbf{6}$ & Hill to hill distance, mm & 250 \\
\hline $\mathbf{7}$ & Width of cut, mm & 220 \\
\hline $\mathbf{8}$ & Average field capacity, ha/h & 0.044 \\
\hline $\mathbf{9}$ & Average field efficiency, \% & 67.19 \\
\hline $\mathbf{1 0}$ & Average weeding efficiency, $\%$ & 81.88 \\
\hline $\mathbf{1 1}$ & Plant damage, $\%$ & 1.44 \\
\hline $\mathbf{1 2}$ & Fuel consumption, $\mathrm{l} / \mathrm{h}$ & 0.665 \\
\hline
\end{tabular}

Table.2 Energy consumption and cost of operation for manual weeding Vs mechanical weeding

\begin{tabular}{|l|l|l|l|}
\hline S No & Particulars & Manual weeding & Mechanical weeding \\
\hline $\mathbf{1}$ & Man hours (h/ha) & 227 & 22.70 \\
\hline $\mathbf{2}$ & Human energy (MJ/ha) & 356.39 & 44.49 \\
\hline $\mathbf{3}$ & Machine energy (MJ/ha) & & 08.69 \\
\hline $\mathbf{4}$ & Fuel energy (MJ/ha) & & 729.72 \\
\hline $\mathbf{5}$ & Total energy used (MJ/ha) & 356.39 & 782.90 \\
\hline $\mathbf{6}$ & Cost of operation (Rs/ha) & 5108 & 1580 \\
\hline $\mathbf{7}$ & Energy -cost (Rs/MJ) & 14.33 & 2.02 \\
\hline
\end{tabular}

Fig.1 Evaluation of single row power weeder at farmer's field
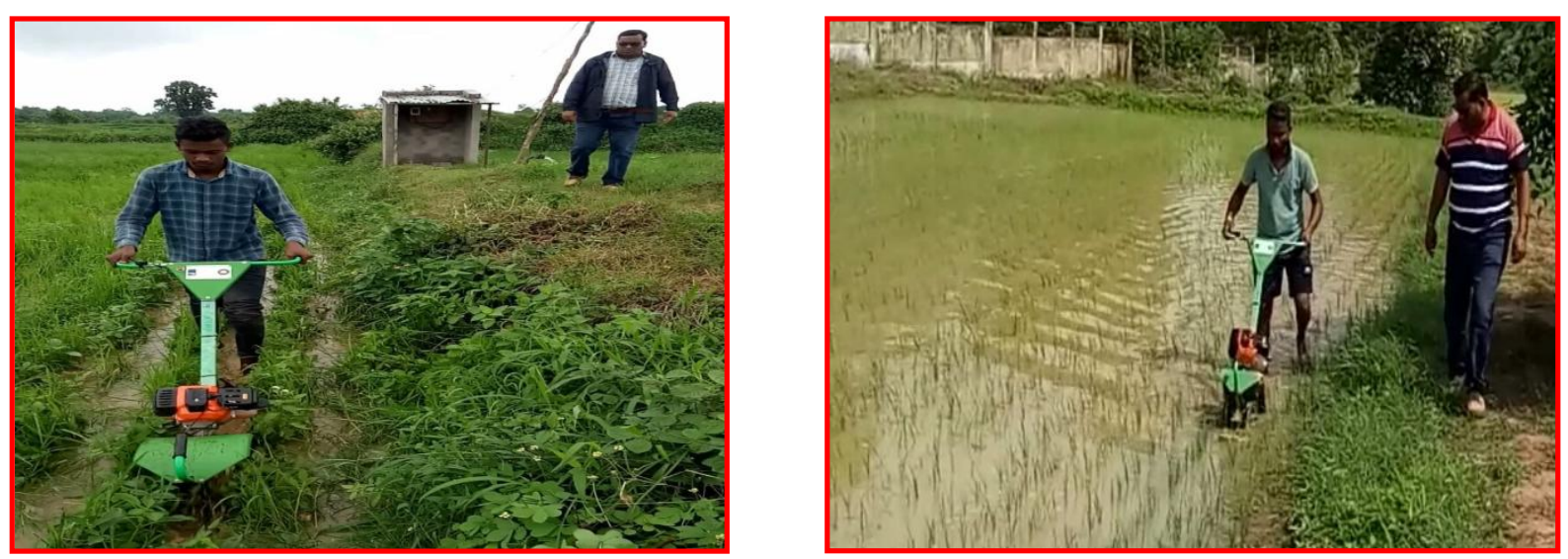


\section{References}

Anonymous. 2014. Annual Report - 2013-14. Department of Agriculture and Cooperation, Ministry of Agriculture, Govt. of India, New Delhi.

Bernacki H; Haman J; KanafojskiCz. 1972. Agricultural Machines, Theory and Construction. Central Institute of Scientific, Technical and Economic Information, Warsaw, Poland, 1: 42628.

Pitoyo, J., and T.M. Handaka (2000). Development of a power weeder for mechanical control of weeds in the nee field. Proc. Int. Agric. Eng. Conf.
Bangkok, Thailand. December 4-7.

Ragesh K. T. 1, S. V. Jogdand and V. M. Victor (2018). Field Performance Evaluation of Power Weeder for Paddy Crop. Current Agriculture Research Journal. Vol. 6(3): 441-448

Tajuddin, A. 2006. Design, development and testing of engine operated weeder. Agric. Eng. Today, 30(5,6): 25-29.

Victor, V.M. and Verma, A. 2003. Design and development of power-operated rotary weeder for wetland rice. Agric. Mechanisation in Asia, Africa and Latin America, 34(4): 27-29.

\section{How to cite this article:}

Narendra H. Tayade and Birbal Sahu. 2020. Performance Evaluation of Power Weeder for Paddy Crop. Int.J.Curr.Microbiol.App.Sci. 9(02): 2291-2295.

doi: https://doi.org/10.20546/ijcmas.2020.902.259 